\title{
FROM THE EDITORS
}

Thank heaven that at long last we are witnessing wider use of antiretroviral therapies in South Africa. There is greater acceptance of these therapies by patients, by doctors and by employer groups. The trend-setting mining giant Anglo American has taken the bold step of providing antiretrovirals for its employees. Regrettably government continues to drag its feet in this regard. Those of us who have used antiretrovirals in our practices continue to be impressed by their beneficial effects, often rescuing patients from death's door. It is however heartening to view antiretroviral therapy (ART) on a larger scale by looking at evidence of its cost-effectiveness in disease management progammes. Dr Leon Regensburg presents very convincing data in the Aid for AIDS programme regarding the cost-beneficial effects of these therapies.

The latest and greatest in the HIV treatment arena, presented at the Barcelona International AIDS Conference in 2002, is described by Dr Francois Venter (p. 29) in his own inimitable style. Dr Jean Nachega has written on ART in developing countries (p. 35), and this is an important focus on the unique problems and challenges of the developing world setting. ART remains one of the most complex challenges facing clinicians today, and when treating

\section{A BIZARRE BATTLE}

Joep Lange, President of the International AIDS Society (IAS), said at the Durban 2000 AIDS conference that no greater ill befalls the poor than bad government, and I am afraid that there is no more unfortunate example of this than the Mpumalanga Provincial Health Department, headed up by MEC Sibongile Manana.

This lady has, in her position of power, decided to systematically ignore World Health Organisation recommendations, international scientific evidence and our own country's constitutional court ruling on antiretrovirals to deny the population in her province access to what is now standard practice in a number of South African provinces. HIV prophylaxis for rape victims and mother-tochild prevention programmes are becoming integrated into public sector health provision in many areas, but in Mpumalanga not only is this not happening within the government, but this same government is wasting valuable AIDS money to fight futile court cases to stop a nongovernmental organisation that has undertaken to fill this very important service gap at its own expense!

To add insult to injury the MEC has taken this organisation patients a high index of awareness is necessary to avoid potentially fatal conditions that are associated with these therapies. All clinicians should read Dr Jennifer Pitt's article (p. 38) on lactic acidosis in order to familiarise themselves with the clinical presentation of this potentially fatal condition. The challenge is that the initial symptoms are often vague and nonspecific.

The Guidelines section (p. 25) is devoted to legal and ethical issues and is presented by Elsabe Klinck from the South African Medical Assocation. These issues are as important to comply with as any other aspects of treatment. The broader aspects of the ethical issues in HIV medicine are highlighted in a thought-provoking article by Dr Dave Spencer (p. 15).

This issue of the journal also features an interesting case study on the immune reconstitution syndrome by Dr David Brittain. We aim to have similar illustrative case studies in all future issues.

\section{DES MARTIN}

Editor, Southern African Journal of HIV Medicine President, Southern African HIV Clinicians Society

to court not just once but an astounding four times over the past 2 years, and has wasted tens of thousands of taxpayer rands in legal fees. Tragically, a number of seemingly innocent people have lost jobs in this province as a result of the same bizarre battle. We reported some months ago in this column that Dr Thys von Mollendorf, the medical superintendent who had allowed the NGO to operate within his hospital, was suspended. I was shocked to learn from recent newspaper reports that his suspension has not been lifted and that he practises in the area from a number of private practices.

It would appear that the public sector, so much in need of good people, has lost someone valuable. If the only reason for his suspension is that he has allowed an NGO to provide for his patients what the rest of the world considers to be standard levels of health care, and what our constitutional court has ruled as part of basic human rights, then the wrong person has been punished. I believe that the medical fraternity needs to find a way to say this with one voice - repeatedly and forcefully.

\section{LINDA-GAIL BEKKER}

Managing Editor 